\title{
Difficulties in Advancement of Science and Shaping the System of Science and University as a Carrier of Technological Development in Bosnia and Herzegovina
}

\author{
Dejan Milošević* \\ Benjamin Fetic ${ }^{* *}$
}

\begin{abstract}
The primary function of the university, in addition to education, is scientific research. At Bosnia and Herzegovina universities, the scientific research has been neglected. There are two basic reasons for that. The first is insufficient financial investment in science and research, and the second is an underdeveloped awareness of the importance of scientific research work, both in the society of Bosnia and Herzegovina and in universities themselves. This paper indicates what needs to be done to overcome this latter difficulty. In addition, the possibilities for improving science and shaping the science system at universities in Bosnia and Herzegovina to make them research universities were analysed. Scientific research work builds on research and development work, technological development, cooperation with the economy and the development of science and technology parks. These activities are even less represented at universities in Bosnia and Herzegovina than scientific research work. This paper shows the ways how to overcome these difficulties, so that research universities become carriers of the technological development of Bosnia and Herzegovina.
\end{abstract}

Key words: Bosnian-Herzegovinian universities, science, research, development, technology

\section{Introduction}

There are eight public universities in Bosnia and Herzegovina, six in the Federation of Bosnia and Herzegovina entity in five cantons (University of Sarajevo, University of Bihać, Džemal Bijedić University in Mostar, University of Mostar, University of Tuzla and University of Zenica) and two in the Republika Srpska entity (University of Banja Luka and University of East Sarajevo). There's also a total of eighteen private universities in Bosnia and Herzegovina - nine of them in the Federation of Bosnia and Herzegovina,

\footnotetext{
${ }^{*}$ Full member of the Academy of Sciences and Arts of Bosnia and Herzegovina. Full professor at the Faculty of Science, University of Sarajevo. E-mail: milo@bih.net.ba

** Assistant professor at the Faculty of Science, University of Sarajevo.

E-mail: benjamin.fetic@pmf.unsa.ba
} 
seven in the Republika Srpska and two in the Brčko district. In addition, sixteen independent colleges and privately owned high schools operate in Bosnia and Herzegovina. Unfortunately, there are no data which show to which extent these institutions are engaged in scientific research. ${ }^{1}$ No public or private university has units that have been declared centers of excellence. The connection of these institutions with the economy was assessed as insufficient (Trifković, 2020).

Scientific research projects are classified as fundamental, applied or research-development (Trifković, 2020). In addition to education, scientific research is a basic function of the university. Unfortunately, scientific research at the universities of Bosnia and Herzegovina has been neglected. This can be shown by analyzing the position of Bosnian-Herzegovinian science and Bosnian-Herzegovinian universities in world rankings. Within the project "Harmonization of the Science System in Bosnia and Herzegovina" (Trifković, 2020) of the Academy of Sciences and Arts of Bosnia and Herzegovina, it was shown that the main reason for unsatisfactory state of science in Bosnia and Herzegovina is its polycentric and atrophied organization. The proposed measures for improving the state of science are based on the harmonization of the science system through the legislation of the relevant political-territorial units. It was pointed out that, in addition to harmonizing existing and passing new laws, it is necessary to revise existing strategies, strengthen and modernize appropriate public administration capacities, separate budget funding for research and technological development activities from funding for the teaching component of higher education, and significantly increase allocations for science, in relation to the current $0.1 \%$ of gross national income, determine priorities in international cooperation and form science councils.

Most of the above proposed measures to improve the position of science are "top-down" type, i.e. it is envisaged that decisions are made at a higher level (e.g. change of law, adoption of strategies) with the expectation that this will lead to the desired changes. Unfortunately, the reality of B\&H society is that laws are interpreted differently and strategies are not implemented. Authorities do not understand how important science is for society. There is no state ministry of science because, according to the Constitution of Bosnia and Herzegovina, education, together with scientific research, is the responsibility of the cantons in the Federation of Bosnia and Herzegovina, and of the

\footnotetext{
${ }^{1}$ See: Answers to the Questionnary of the European Commission - Chapter 25 - Science and research, The Directorate for European Integration of the Council of Ministers of Bosnia and Herzegovina, DEI | Answers to the Questionnaire. (November 2, 2020)
} 
Republika Srpska entity. Legislation depends on the levels of government, so only partial solutions are made. There is no policy of the competent institutions for the return of the top students who left Bosnia and Herzegovina for the purpose of education. The personnel policy of universities is inadequate, i.e. it practically does not exist. This paper points out the possibility of a different approach. The "bottom-up" approach should gradually lead to a change in the awareness of the government and individuals about the importance of science and scientific research for the development of Bosnian-Herzegovinian society. It is necessary to create a critical mass of scientists who are really engaged in scientific research, which can be measured by exact indicators established by international standards and criteria, such as the number and quality of published papers monitored by the Web of Science Core Collection database, h-index and the like.

After this introduction, in the following chapters we will first present the exact indicators of the position of Bosnian-Herzegovinian science and Bosnian-Herzegovinian universities in the world. The obtained results are based on the analysis of carefully selected world rankings. After that, we will present the Strategy for the Development of Scientific Research/Artistic Research at the University of Sarajevo and the Regulation on Rewarding Academic and Scientific Research Staff of the University of Sarajevo based on the results of scientific/artistic work as examples of "bottom-up" measures to improve science in Bosnia and Herzegovina. We will also present the results of the analysis of the number and citations of papers affiliated with the University of Sarajevo. The remaining part of the paper presents data on institutes, research centers, technology parks and patents in Bosnia and Herzegovina. The weaknesses of the data collection system on scientific research work were pointed out. Funding and problems of realization of employment of scientists and researchers were considered immediately before the conclusions with which this work ends.

\section{The Position of Bosnian-Herzegovinian Science in the World}

The position of a country's science in the world is determined by the contribution of that country's scientists to scientific production expressed by the number and importance of scientific publications. There are different ranking lists of countries. ${ }^{2}$

\footnotetext{
${ }^{2}$ Academic ranking, Agency for science and higher education, Zagreb, 2019 (brochure printed as a part of the SKAZVO: https://skazvo.azvo.hr/images/stories/dokumenti/24 Bro\%C5\%A1ura_Akademska_rangiranja.pdf).
} 
For example, Nature index ${ }^{3}$ is a database based on papers published in a selected group of 82 high quality journals. Since the number of such papers published by Bosnian-Herzegovinian authors is negligible, we decided to analyze the data available on The SCImago Journal \& Country Rank portal. ${ }^{4}$ The analysis of publishing and citing in over 34 thousand titles according to a specific algorithm (Guerrero-Botea \& Moya-Anegón, 2012) ranked 239 countries. The order for 2019 is: China, the United States, Great Britain, India, Germany, Italy, Japan, France, Canada, the Russian Federation, Australia, Spain, etc. Table 1 shows the position of Bosnia and Herzegovina based on published scientific papers according to the SCImago Journal \& Country Rank in the period from 1996 to 2020 . The ranking of countries in our environment is also stated. The conclusion is that we are significantly behind compared to Serbia, Croatia and Slovenia, but that we are better than Macedonia, Montenegro and Albania. Considering the pre-war development of these states, this result is expected. It is interesting to note that, unlike the surrounding countries, the position of Bosnia and Herzegovina on this ranking list has improved over the recent years. However, the difference of over thirty places on the world ranking list in relation to Serbia, Croatia and Slovenia is too big and can be attributed to the poor attitude of $\mathrm{B} \& \mathrm{H}$ authorities towards science and scientific research, as well as insufficiently developed awareness of academia members about the importance of scientific research.

Table 1. Ranking of Bosnia and Herzegovina and the countries in its vicinity in the period 1996-2020 according to the SCImago Journal \& Country Rank portal. (June 1, 2021)

\begin{tabular}{lccccccc}
\hline Country & $1996-2020$ & 2015 & 2016 & 2017 & 2018 & 2019 & 2020 \\
\hline B\&H & 96 & 92 & 92 & 92 & 93 & 92 & 92 \\
\hline Serbia & 52 & 50 & 51 & 51 & 54 & 54 & 56 \\
\hline Croatia & 50 & 52 & 53 & 53 & 55 & 59 & 58 \\
\hline Slovenia & 53 & 53 & 55 & 55 & 59 & 60 & 60 \\
\hline Macedonia & 97 & 93 & 95 & 95 & 95 & 98 & 101 \\
\hline Montenegro & 122 & 118 & 112 & 111 & 114 & 112 & 114 \\
\hline Albania & 118 & 107 & 117 & 126 & 116 & 118 & 119 \\
\hline
\end{tabular}

\footnotetext{
${ }^{3} \mathrm{https}: / /$ www.natureindex.com/

${ }^{4} \mathrm{https}$ ://www.scimagojr.com. This portal uses database information Scopus ${ }^{\circledR}$ (www.scopus. com; Elsevier B.V.: www.elsevier.com).
} 


\section{Position of Bosnian-Herzegovinian Universities on the Webometrics List}

In the last few years, the management of the University of Sarajevo has made a significant effort to advance the position of the university in the world rankings. This is especially true for Webometrics ranking that includes all universities in the world. Namely, the academic staff of the University of Sarajevo publishes negligibly small number of papers in top scientific journals, so the University of Sarajevo is not ranked at all on prestigious world rankings such as the Shanghai list. When ranking by Webometrics, four criteria are used according to Table 2.

Table 2. Ranking criteria according to Webometrics.

\begin{tabular}{lllc}
\hline INDICATORS & METHODOLOGY & SOURCE & WEIGHT \\
\hline PRESENCE & $\begin{array}{l}\text { Web domain size of the institution (with subdomains) - also includes } \\
\text { the number of documents placed on the domain and sub-domains as } \\
\text { rich text, pdf. }\end{array}$ & Google & $5 \%$ \\
\hline VISIBILITY & $\begin{array}{l}\text { Visibility (number of external networks (subnets) linking to the } \\
\text { institution's webpages. }\end{array}$ & $\begin{array}{c}\text { Ahrefs } \\
\text { Majestic }\end{array}$ & $50 \%$ \\
\hline $\begin{array}{l}\text { TRANSPARENCY } \\
\text { (or OPENNESS) }\end{array}$ & $\begin{array}{l}\text { Number of citations from top 10 authors of institution at Google } \\
\text { Scholar (citations from the second to the tenth ranked author are } \\
\text { collected, while the number of citations of the first is not added). }\end{array}$ & $\begin{array}{l}\text { Google } \\
\text { Scholar } \\
\text { Citations }\end{array}$ & \multirow{2}{*}{$10 \%$} \\
\hline $\begin{array}{l}\text { EXCELLENCE } \\
\text { (or SCHOLAR) }\end{array}$ & $\begin{array}{l}\text { Number of published papers among 10\% of the most cited papers } \\
\text { in 26 disciplines over a period of five years. }\end{array}$ & Scimago & $35 \%$ \\
\hline
\end{tabular}

According to the Webometrics list from July 2020, the order of universities from our region is as follows (in parentheses is the ranking in the world): 1. Ljubljana (314), 2. Belgrade (441), 3. Zagreb (590), 4. Novi Sad (934), 5. Split (1098), 6. Maribor (1118), 7. Niš (1397), 8. Rijeka (1420), 9. Sarajevo (1508). Among the first 2000 universities are also: Skopje (1556), Kragujevac (1750), University of Montenegro (1915) and Osijek (1993). As expected, the universities in Ljubljana, Belgrade and Zagreb are far ahead of the University of Sarajevo, which is the best-ranked university in Bosnia and Herzegovina. According to tradition and pre-war position, the University of Sarajevo should be in the rank of the University of Novi Sad, and ahead of the Universities of Split, Maribor, Niš and Rijeka. Other universities in Bosnia and Herzegovina are ranked below the 3000th place (see Table 3). Thus, it is clear that the universities in Bosnia and Herzegovina, which should be the bearers of science and scientific research, are ranked far below expectations. This gap is even 
larger if only the criterion of scientific excellence is taken into account (the criterion of "excellence" contributes $35 \%$ according to Table 2; compare the last column in Table 3). The reasons for this failure of Bosnian science are listed in the Introduction.

Table 3. Ranking list of the first 14 universities in Bosnia and Herzegovina according to Webometrics.

\begin{tabular}{cclcccc}
\hline Ranking & World & University & Presence & Impact & Openness & Excellence \\
\hline 1 & 1508 & University of Sarajevo & 905 & 1979 & 1209 & 2214 \\
\hline 2 & 3107 & University of Tuzla & 1228 & 5553 & 1870 & 4011 \\
\hline 3 & 3604 & International University of Sarajevo & 1120 & 6976 & 3472 & 4064 \\
\hline 4 & 3800 & International BURCH University Sarajevo & 3767 & 7529 & 3762 & 4011 \\
\hline 5 & 3882 & University of Banja Luka & 970 & 5861 & 5819 & 3383 \\
\hline 6 & 4767 & University of Mostar & 940 & 12342 & 2531 & 4942 \\
\hline 7 & 5478 & University of East Sarajevo & 1871 & 20450 & 2883 & 4011 \\
\hline 8 & 6463 & Sarajevo School of Science \&Technology & 17018 & 12688 & 4394 & 5379 \\
\hline 9 & 6732 & European University „Kallos“ Tuzla & 11938 & 4117 & 5593 & 6626 \\
\hline 10 & 6881 & European University Brčko & 10345 & 3724 & 5819 & 6626 \\
\hline 11 & 8378 & University of Bihać & 9031 & 13550 & 5018 & 5902 \\
\hline 12 & 9240 & University „Džemal Bijedić ${ }^{\prime \prime}$ Mostar & 7267 & 11634 & 4329 & 6626 \\
\hline 13 & 10866 & International University Travnik & 12903 & 8983 & 5819 & 6626 \\
\hline 14 & 11916 & University of Zenica & 3519 & 23196 & 3706 & 5681 \\
\hline
\end{tabular}

We note that the latest position of the University of Sarajevo in the 1508th place in the world is the best so far. This is the result of hard work on increasing the presence and visibility of the web assets of the University of Sarajevo (creation of a new website) and the requirement for academic staff and researchers to register on Google scholar. ${ }^{5}$ This can be seen by the fact that the University of Sarajevo is ranked much better in terms of presence (905) and transparency (1209). This was achieved in a relatively short period of time. The University of Sarajevo lags behind in terms of the influence criterion (1979) (this criterion carries 50\% of the ranking; simply put, when calculating this criterion, all external links that the university's web domain receives from third parties are taken into account). These results indicate that it is possible to improve the position of science in Bosnia and Herzegovina using the "bottom-up" approach. In addition to the University of Sarajevo, it is planned

\footnotetext{
${ }^{5}$ https://scholar.google.com/
} 
to improve the position of other universities. ${ }^{6}$ It is obvious that the University of Sarajevo lags behind the most in terms of excellence (2214), which contributes $35 \%$ to the overall ranking. Improving excellence can only be achieved through long-term measures. This, of course, includes the "top-down" measures mentioned in the introduction. Examples of long-term "bottom-up" measures are the Strategy for the Development of Scientific Research/ Artistic Research at the University of Sarajevo and the Regulation on Rewarding Academic and Scientific Research Staff of the University of Sarajevo based on the results of scientific/artistic work discussed in the following parts.

\section{Strategy for Development of Scientific Research/ Artistic Research Work at the University of Sarajevo}

The Council for Science and Arts of the University of Sarajevo is an expert and advisory body of the Senate of the University of Sarajevo appointed by the decision of the Senate of December 28, 2016. The basic document relevant to this paper is the Strategy for the Development of Scientific Research / Artistic Research at the University of Sarajevo, which was adopted on September 22, 2017 at the Senate session, at the proposal of the Council. ${ }^{7}$ This strategy envisages that excellent research and publication of quality works are especially encouraged and rewarded. The second chapter of this strategy (2. Creating criteria of scientific excellence and relevance) in the section "New criteria for academic promotions and incentives for outstanding researchers" states that: "Scientific papers should include papers published in scientific journals represented in the WoSCC database (Web of Science Core Collection). When drafting the Regulation on election to academic titles, which will establish a scoring system for the evaluation of scientific papers as a condition for election to academic titles, pay special attention to JR (Journal Citation Reports) and SJR (SCImago Journal Rank indicator) and, accordingly, classify scientific journals according to their importance in their field (e.g. in the so-called quartiles Q1, Q2, Q3 and Q4).”

In the conclusion of the Strategy for the Development of Scientific Research / Artistic Research at the University of Sarajevo, it was emphasized that the key elements for the implementation of this strategy are:

\footnotetext{
${ }^{6}$ Milošević, D. The role, significance, promotion and popularization of science in B\&H: Example of the University of Sarajevo, lecture, University „Džemal Bijedić“ Mostar, December 24, 2019; contacts with colleagues from the University of Tuzla, etc.

${ }^{7}$ Strategy | University of Sarajevo (unsa.ba)
} 
,- formation of registers of scientific / artistic works, researchers / artists, projects and infra-structure,

- activation / establishment of a center for research and development of the University of Sarajevo (and within it a science and technology park),

- new criteria for promotion to academic titles and incentives for excellent research,

- reforms and improvement of doctoral studies as an important segment of scientific research and general development of the academic community,

- rationalization of the existing scientific research infrastructure and planned procurement of crucial equipment."

The above mentioned registers have not yet been formed. The UNSA Research and Development Center has been established but has not yet been activated. Criteria for incentives for outstanding researchers have been adopted and outstanding researchers have been awarded for results in 2017, 2018 and 2019. Criteria for promotion to academic titles has yet to be drafted and adopted. New rules for doctoral studies have been adopted. For the rationalization of the existing scientific research infrastructure and the planned procurement of crucial equipment, it is necessary to first form a register and make an appropriate analysis based on it.

\section{Regulation on Awarding the Academic and Scientific Research Staff of the University of Sarajevo on the Basis of the Results of Scientific / Artistic Work}

As another example of "bottom-up" improvement of the quality and position of science, we will cite the Regulation on rewarding academic and scientific research staff of the University of Sarajevo based on the results of scientific / artistic work. ${ }^{8}$ The Senate of the University of Sarajevo has adopted this Regulation at the 19th session held on May 29, 2018. Prior to this adoption, an analysis of papers published in 2017 with the affiliation of the University of Sarajevo according to the Web of Science Core Collection database was conducted. Based on the results of that analysis, the Regulation is designed to achieve the most equal evaluation of the contribution of scientists from different fields. Tables 4, 5 and 6 present the results for 2017, 2018 and 2019. ${ }^{9}$ For each group of sci-

\footnotetext{
8 https:/www.unsa.ba/o-univerzitetu/propisi/pravilnik-o-nagradivanju-akademskog-i-naucnoistrazivackog-osoblja

${ }^{9}$ The data in the given tables were processed by the Service for Scientific Research of the University of Sarajevo.
} 
Dejan Milošević, Benjamin Fetić: Difficulties in Advancement of Science and Shaping the System of Science...

ences and each organizational unit, the number of papers published in journals accompanied by a certain quartile (Q1, Q2, Q3 and Q4) is presented. ${ }^{10}$

Table 4. List of the number of published papers and points for 2017 by groups and organizational units of the University of Sarajevo according to the Regulation on

rewarding.

\begin{tabular}{|c|c|c|c|c|c|c|c|c|c|c|c|c|c|}
\hline GRUPACIJA & $\begin{array}{c}\begin{array}{c}\text { Organizaciona } \\
\text { jedinica/institucija }\end{array} \\
\end{array}$ & Wos Docs & $\begin{array}{c}\text { Docs in JIF } \\
\text { Journals }\end{array}$ & $\begin{array}{c}\text { Docs in } \\
\text { Q1 } \\
\text { Journals }\end{array}$ & $\begin{array}{c}\text { Docs in } \\
\text { Q2 } \\
\text { Journals }\end{array}$ & $\begin{array}{c}\text { Docs in } \\
\text { Q3 } \\
\text { Journals }\end{array}$ & $\begin{array}{c}\text { Docs in } \\
\text { Q4 } \\
\text { Journals }\end{array}$ & $\begin{array}{c}\text { Docs } \\
\text { other } \\
\text { than JIF }\end{array}$ & Q1 (10) & $\mathrm{Q} 2(7)$ & $\mathrm{Q} 3(4)$ & $\mathrm{Q} 4(2)$ & $\begin{array}{l}\text { UKUPNO } \\
\text { BODOVA }\end{array}$ \\
\hline \multirow{2}{*}{ Društvene nauke } & Ekonomski fakultet & 25 & 13 & 3 & 5 & 3 & 2 & 12 & 30 & 35 & 12 & 4 & 93 \\
\hline & Pravni fakultet & 1 & 0 & 0 & 0 & 0 & 0 & 1 & 0 & 0 & 0 & 0 & 1 \\
\hline \multirow{2}{*}{ Humanističke nauke } & Filozofski fakultet & 6 & 3 & 0 & 2 & 1 & 0 & 3 & 0 & 14 & 4 & 0 & 21 \\
\hline & Pedagoški fakultet & 2 & 2 & 0 & 0 & 1 & 1 & 0 & 0 & 0 & 4 & 2 & 6 \\
\hline \multirow{5}{*}{ Medicinske nauke } & $\begin{array}{l}\text { Fakultet zdravstvenih } \\
\text { studija }\end{array}$ & 1 & 1 & 1 & 0 & 0 & 0 & 0 & 10 & 0 & 0 & 0 & 10 \\
\hline & Farmaceutski fakultet & 10 & 10 & 2 & 2 & 0 & 6 & 0 & 20 & 14 & 0 & 12 & 46 \\
\hline & Medicinski fakultet & 40 & 38 & 6 & 12 & 18 & 2 & 2 & 60 & 84 & 72 & 4 & 222 \\
\hline & Stomatološki fakultet & 8 & 4 & 0 & 4 & 0 & 0 & 4 & 0 & 28 & 0 & 0 & 32 \\
\hline & Veterinarski fakultet & 12 & 12 & 6 & 2 & 3 & 1 & 0 & 60 & 14 & 12 & 2 & 88 \\
\hline \multirow{4}{*}{$\begin{array}{c}\text { Prirodno- } \\
\text { matematičke i } \\
\text { biotehničke nauke }\end{array}$} & INGEB & 10 & 10 & 0 & 3 & 5 & 2 & 0 & 0 & 21 & 20 & 4 & 45 \\
\hline & PMF & 103 & 97 & 22 & 10 & 32 & 31 & 6 & 220 & 70 & 128 & 62 & 486 \\
\hline & \begin{tabular}{|l|} 
Poljoprivredno- \\
prehrambeni fakultet
\end{tabular} & 14 & 14 & 3 & 6 & 0 & 5 & 0 & 30 & 42 & 0 & 10 & 82 \\
\hline & Šumarski fakultet & 14 & 13 & 5 & 3 & 1 & 4 & 1 & 50 & 21 & 4 & 8 & 84 \\
\hline \multirow{4}{*}{ Tehničke nauke } & ETF & 9 & 9 & 1 & 2 & 2 & 4 & 0 & 10 & 14 & 8 & 8 & 40 \\
\hline & $\begin{array}{l}\begin{array}{l}\text { Fakultet za saobraćaj i } \\
\text { komunikacije }\end{array} \\
\end{array}$ & 2 & 2 & 1 & 0 & 0 & 1 & 0 & 10 & 0 & 0 & 2 & 12 \\
\hline & Građevinski fakultet & 11 & 11 & 2 & 2 & 0 & 7 & 0 & 20 & 14 & 0 & 14 & 48 \\
\hline & Mašinski fakultet & 10 & 10 & 0 & 2 & 0 & 8 & 0 & 0 & 14 & 0 & 16 & 30 \\
\hline
\end{tabular}

Table 5. List of the number of published papers and points for 2018 by groups and organizational units of the University of Sarajevo according to the Regulation on

rewarding.

\begin{tabular}{|c|c|c|c|c|c|c|c|c|c|c|c|c|c|}
\hline GRUPACIJA & $\begin{array}{c}\text { Organizaciona } \\
\text { jedinica/institucija }\end{array}$ & WoS Docs & $\begin{array}{c}\begin{array}{c}\text { Docs in } \\
\text { JIF } \\
\text { Journals }\end{array} \\
\end{array}$ & $\begin{array}{c}\text { Docs in } \\
\text { Q1 } \\
\text { Journals }\end{array}$ & $\begin{array}{c}\text { Docs in } \\
\text { Q2 } \\
\text { Journals }\end{array}$ & $\begin{array}{c}\text { Docs in } \\
\text { Q3 } \\
\text { Journals }\end{array}$ & $\begin{array}{c}\text { Docs in } \\
\text { Q4 } \\
\text { Journals }\end{array}$ & $\begin{array}{c}\begin{array}{c}\text { Docs } \\
\text { other } \\
\text { than JIF }\end{array} \\
\end{array}$ & Q1 (10) & Q2 (7) & Q3 (4) & $\mathrm{Q} 4(2)$ & $\begin{array}{l}\text { UKUPNO } \\
\text { BODOVA }\end{array}$ \\
\hline \multirow{3}{*}{ Društvene nauke } & Ekonomski fakultet & 27 & 8 & 1 & 3 & 3 & 1 & 19 & 10 & 21 & 12 & 2 & 64 \\
\hline & Fakultet političkih nauka & 5 & 2 & 0 & 0 & 2 & 0 & 3 & 0 & 0 & 8 & 0 & 11 \\
\hline & $\begin{array}{l}\begin{array}{l}\text { Fakultet sporta i tjelesnog } \\
\text { odgoja }\end{array} \\
\end{array}$ & 21 & 7 & 0 & 0 & 0 & 7 & 14 & 0 & 0 & 0 & 14 & 28 \\
\hline \multirow{3}{*}{ Humanističke nauke } & Filozofski fakultet & 11 & 7 & 2 & 5 & 0 & 0 & 4 & 20 & 35 & 0 & 0 & 59 \\
\hline & $\begin{array}{l}\begin{array}{l}\text { Katolički bogoslovni } \\
\text { fakultet }\end{array} \\
\end{array}$ & 1 & 0 & 0 & 0 & 0 & 0 & 1 & 0 & 0 & 0 & 0 & 1 \\
\hline & Pedagoški fakultet & 11 & 1 & 1 & 0 & 0 & 0 & 10 & 10 & 0 & 0 & 0 & 20 \\
\hline \multirow{5}{*}{ Medicinske nauke } & $\begin{array}{l}\text { Fakultet zdravstvenih } \\
\text { studija }\end{array}$ & 2 & 2 & 1 & 0 & 1 & 0 & 0 & 10 & 0 & 4 & 0 & 14 \\
\hline & Farmaceutski fakultet & 60 & 19 & 2 & 4 & 7 & 6 & 41 & 20 & 28 & 28 & 12 & 129 \\
\hline & Medicinski fakultet & 51 & 27 & 3 & 9 & 8 & 7 & 24 & 30 & 63 & 32 & 14 & 163 \\
\hline & Stomatološki fakultet & 3 & 0 & 0 & 0 & 0 & 0 & 3 & 0 & 0 & 0 & 0 & 3 \\
\hline & Veterinarski fakultet & 36 & 35 & 17 & 4 & 12 & 2 & 1 & 170 & 28 & 48 & 4 & 251 \\
\hline \multirow{4}{*}{$\begin{array}{c}\text { Prirodno- } \\
\text { matematičke i } \\
\text { biotehničke nauke }\end{array}$} & INGEB & 22 & 22 & 1 & 0 & 10 & 11 & 0 & 10 & 0 & 40 & 22 & 72 \\
\hline & PMF & 124 & 88 & 18 & 30 & 26 & 14 & 36 & 180 & 210 & 104 & 28 & 558 \\
\hline & $\begin{array}{l}\text { Poljoprivredno- } \\
\text { prehrambeni fakultet }\end{array}$ & 41 & 36 & 3 & 14 & 9 & 10 & 5 & 30 & 98 & 36 & 20 & 189 \\
\hline & Šumarski fakultet & 27 & 19 & 3 & 5 & 4 & 7 & 8 & 30 & 35 & 16 & 14 & 103 \\
\hline \multirow{4}{*}{ Tehničke nauke } & Arhitektonski fakultet & 1 & 1 & 1 & 0 & 0 & 0 & 0 & 10 & 0 & 0 & 0 & 10 \\
\hline & ETF & 33 & 27 & 2 & 6 & 10 & 9 & 6 & 20 & 42 & 40 & 18 & 126 \\
\hline & Građevinski fakultet & 24 & 16 & 3 & 1 & 2 & 10 & 8 & 30 & 7 & 8 & 20 & 73 \\
\hline & Mašinski fakultet & 32 & 10 & 0 & 3 & 3 & 4 & 22 & 0 & 21 & 12 & 8 & 63 \\
\hline Umjetnost & Muzička akademija & 2 & 2 & 0 & 0 & 2 & 0 & 0 & 0 & 0 & 8 & 0 & 8 \\
\hline
\end{tabular}

${ }^{10}$ The quartile ranking is based on the impact factor (IF) of the journal according to the Journal Citation Reports (JCR) published by Clarivate Analytics each year. Information can be obtained through the Web of Science Core Collection. Q1 joins the best journals (ranked in the top 25\%), Q2 corresponds to 25-50\%, Q3 - 50-75\%, and Q4 the last 75-100\% of journals according to IF. 
Table 6. List of the number of published papers and points for 2019 by groups and organizational units of the University of Sarajevo according to the Regulation on rewarding.

\begin{tabular}{|c|c|c|c|c|c|c|c|c|c|c|c|c|c|}
\hline \multicolumn{14}{|c|}{ SAVJET ZA NAUKU I UMJETNOST UNIVERZITETA U SARAJEVU } \\
\hline \multicolumn{14}{|c|}{ UTVREENA LISTA RADOVA I BODOVA PO ORGANIZACIONIM JEDINICAMA U SKLADU SA PRAVILNIKOM O NAGRAEIVANJU (2019. GODINA) } \\
\hline \multicolumn{14}{|c|}{ OJ lista za nagrade } \\
\hline & & & & & & & & & & BODOV & ANJE & & \\
\hline GRUPACIJA & Organizaciona jedinica/institucija & WoS Docs & $\begin{array}{c}\text { Docs in JIF } \\
\text { Journals }\end{array}$ & $\begin{array}{c}\text { Docs in } \\
\text { Q1 } \\
\text { Journals }\end{array}$ & \begin{tabular}{c|} 
Docs in \\
Q2 \\
Journals
\end{tabular} & $\begin{array}{c}\text { Docs in } \\
\text { Q3 } \\
\text { Journals }\end{array}$ & $\begin{array}{c}\text { Docs in } \\
\text { Q4 } \\
\text { Journals }\end{array}$ & \begin{tabular}{|c|} 
Docs \\
other \\
than JIF
\end{tabular} & Q1 (10) & Q2 (7) & Q3 (4) & $\mathrm{Q} 4$ (2) & $\begin{array}{l}\text { UKUPNO } \\
\text { BODOVA }\end{array}$ \\
\hline \multirow{5}{*}{ Društvene nauke } & Ekonomski fakultet & 36 & 22 & 9 & 7 & 5 & 1 & 14 & 90 & 49 & 20 & 2 & 175 \\
\hline & Fakultet političkih nauka & 5 & 1 & 0 & 1 & 0 & 0 & 4 & 0 & 7 & 0 & 0 & 11 \\
\hline & Fakultet sporta i tjelesnog odgoja & 10 & 2 & 1 & 0 & 1 & 0 & 8 & 10 & 0 & 4 & 0 & 22 \\
\hline & $\begin{array}{l}\text { Fakultet za kriminalistiku, } \\
\text { kriminologiju i sigurnosne studije }\end{array}$ & 2 & 1 & 1 & 0 & 0 & 0 & 1 & 10 & 0 & 0 & 0 & 11 \\
\hline & Pravni fakultet & 1 & 0 & 0 & 0 & 0 & of & 1 & 0 & 0 & 0 & 0 & 1 \\
\hline \multirow{4}{*}{ Humanističke nauke } & Filozofski fakultet & 18 & 1 & 1 & 0 & 0 & 0 & 17 & 10 & 0 & 0 & 0 & 27 \\
\hline & Katolički bogoslovni fakultet & 1 & 0 & 0 & 0 & 0 & 0 & 1 & 0 & 0 & 0 & 0 & 1 \\
\hline & Pedagoški fakultet & 10 & 2 & 0 & 0 & 0 & 2 & 8 & 0 & 0 & 0 & 4 & 12 \\
\hline & Institut za historiju & 2 & 0 & 0 & 0 & 0 & 0 & 2 & 0 & 0 & 0 & 0 & 2 \\
\hline \multirow{5}{*}{ Medicinske nauke } & Fakultet zdravstvenih studija & 5 & 4 & 1 & 0 & 1 & 2 & 1 & 10 & 0 & 4 & 4 & 19 \\
\hline & Farmaceutski fakultet & 46 & 26 & 2 & 0 & 10 & 14 & 20 & 20 & 0 & 40 & 28 & 108 \\
\hline & \begin{tabular}{|l|} 
Medicinski fakultet \\
\end{tabular} & 108 & 87 & 28 & 6 & 20 & 33 & 24 & 280 & 42 & 80 & 66 & 492 \\
\hline & Stomatološki fakultet & 4 & 0 & 0 & 0 & 0 & 0 & 4 & 0 & 0 & 0 & 0 & 4 \\
\hline & \begin{tabular}{|l|} 
Veterinarski fakultet \\
\end{tabular} & 19 & 17 & 2 & 1 & 1 & 13 & 2 & 20 & 7 & 4 & 26 & 59 \\
\hline \multirow{4}{*}{$\begin{array}{c}\text { Prirodno- } \\
\text { matematičke i } \\
\text { biotehničke nauke }\end{array}$} & INGEB & 26 & 26 & 2 & 0 & 4 & 20 & 0 & 20 & 0 & 16 & 40 & 76 \\
\hline & PMF & 131 & 105 & 8 & 35 & 28 & 34 & 38 & 80 & 245 & 112 & 68 & 543 \\
\hline & $\begin{array}{l}\text { Poljoprivredno-prehrambeni } \\
\text { fakultet }\end{array}$ & 36 & 24 & 5 & 6 & 3 & 10 & 12 & 50 & 42 & 12 & 20 & 136 \\
\hline & Šumarski fakultet & 42 & 30 & 12 & 0 & 0 & 18 & 12 & 120 & 0 & 0 & 36 & 168 \\
\hline \multirow{4}{*}{ Tehničke nauke } & ETF & 41 & 28 & 15 & 4 & 3 & 6 & 13 & 150 & 28 & 12 & 12 & 215 \\
\hline & $\begin{array}{l}\text { Fakultet za saobracaj i } \\
\text { komunikacije }\end{array}$ & 3 & 1 & 1 & 0 & 0 & 0 & 2 & 10 & 0 & 0 & 0 & 12 \\
\hline & Građevinski fakultet & 29 & 16 & 6 & 1 & 0 & 9 & 13 & 60 & 7 & 0 & 18 & 98 \\
\hline & \begin{tabular}{|l|} 
Mašinski fakultet \\
\end{tabular} & 52 & 19 & 1 & 5 & 11 & 2 & 33 & 10 & 35 & 44 & 4 & 126 \\
\hline \multirow{2}{*}{ Umjetnost } & Akademija likovnih umjetnosti & 1 & 0 & 0 & 0 & 0 & 0 & 1 & 0 & 0 & 0 & 0 & 1 \\
\hline & Muzička akademija & 1 & 0 & 0 & 0 & $2 \mid$ & 0 & 1 & \begin{tabular}{l|l}
0 & -1 \\
\end{tabular} & 0 & 8 & \begin{tabular}{l|l}
0 & \\
\end{tabular} & 9 \\
\hline
\end{tabular}

\section{Analysis of the Number and Quotation of Scientific Papers Published With the Affiliation of the University of Sarajevo}

In this part of the paper, we will analyze the number and citations of scientific papers with the affiliation of the University of Sarajevo (address of the institution "Univ Sarajevo") published in journals monitored by the Web of Science Core Collection database. Papers with the addresses: Int Univ Sarajevo, Burch Univ Sarajevo and SSST are excluded from consideration. Taking into account that the authors did not always take into account the affiliation of the University of Sarajevo (sometimes only the name of the faculty or department is stated), the obtained results cannot be considered complete. However, the results obtained in this way indicate a trend in the development of scientific work at the university.

Figures 1 and 2 show the number of published papers and their citations by years from 1949 to 2019. Four time periods/phases can be observed:

- From 1949 to 1972: This is the period of the beginnings of scientific work at the University of Sarajevo and the number of papers and citations of these papers is small. 
- From 1973 to 1991: In this period there is already a good basis for scientific work and the number of published papers and citations is significantly higher than in the first period and is slightly increasing with age.

- From 1992 to 2004: This is a period of war and renewal of scientific potentials after the war. The number of publications has been reduced.

- From 2005 to 2019: After 2005, there was a sharp increase in the number of published scientific papers and the number of citations. This increase is significantly higher than expected and it would be useful to examine why this occurred. It is possible that this is related to the beginning of the Bologna Process, the introduction of internationalization and the improvement of international cooperation with other universities.

Figure 1. Number of published scientific papers with the affiliation of the University of Sarajevo by years (according to the Web of Science Core Collection for period from 1949 to 2019, accessed through the Max Born Institute in Berlin, 2020).

Total Publications

2.828 Analyze

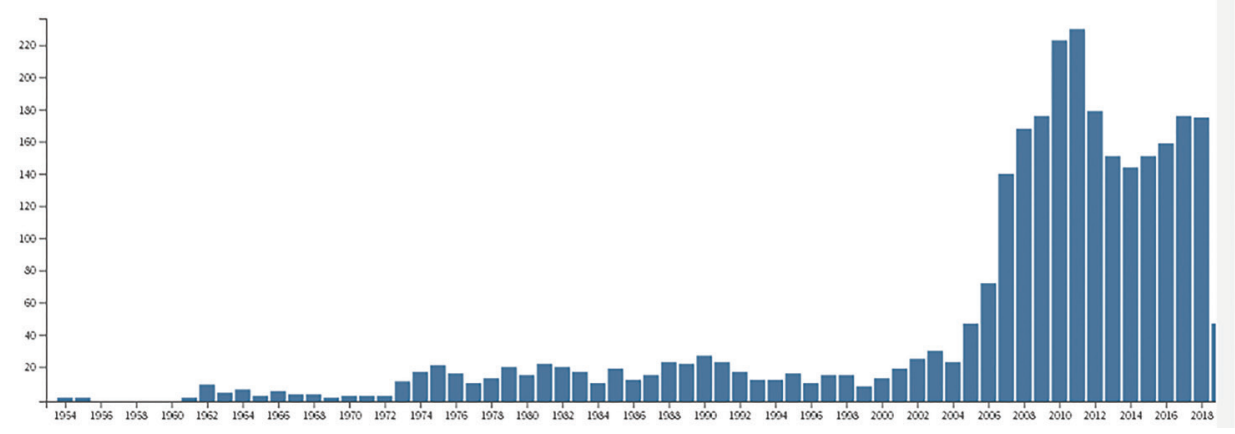

Figure 2. Number of citations for papers from Figure 1.

Sum of Times Cited per Year

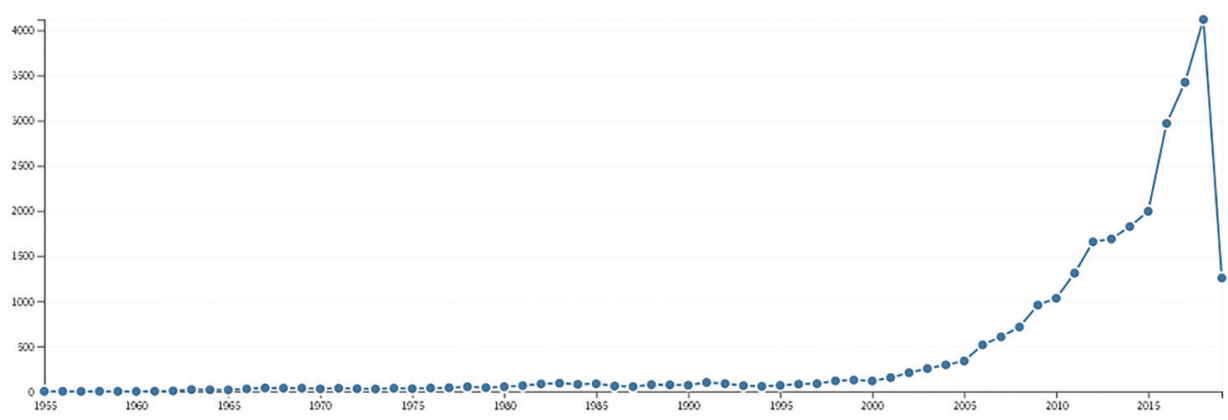


Figure 3 presents an analysis of the number and citations of papers affiliated with the University of Sarajevo according to the Web of Science Core Collection for the period from 1994 to 2020 (the subscription of the University of Sarajevo includes this period). We see that over 4000 papers have been published and that since 2007 the number of papers has risen sharply. After some stagnation in the period 2012-2014 the number of papers and their citation is constantly increasing. This analysis indicates that, despite the poor conditions in which scientific research takes place, our contribution to world scientific production is on the rise.

Figure 3. Number of published papers by years from 1994 to 2020.11

Total Publications

4,012 Analyze

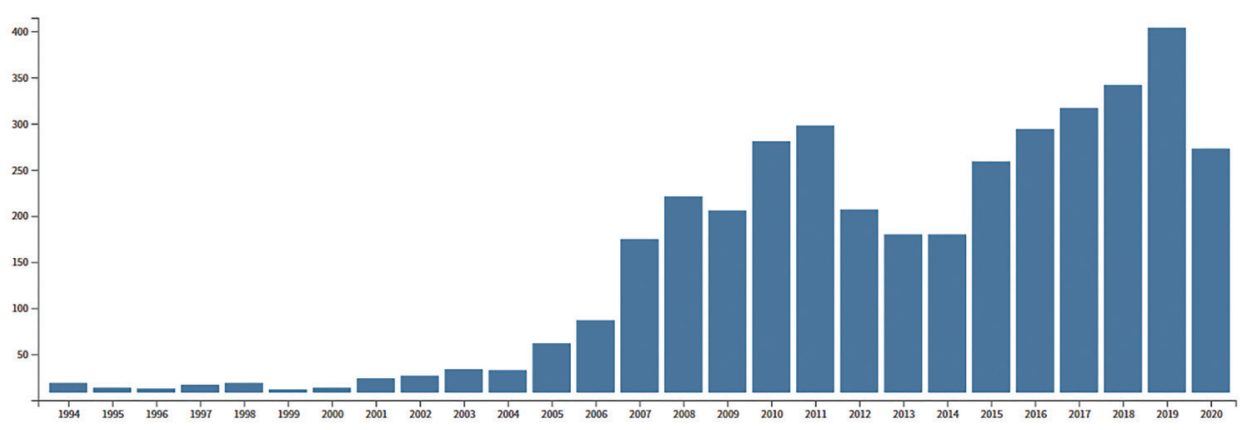

Figure 4. Number of citations per year for papers from Figure 3.

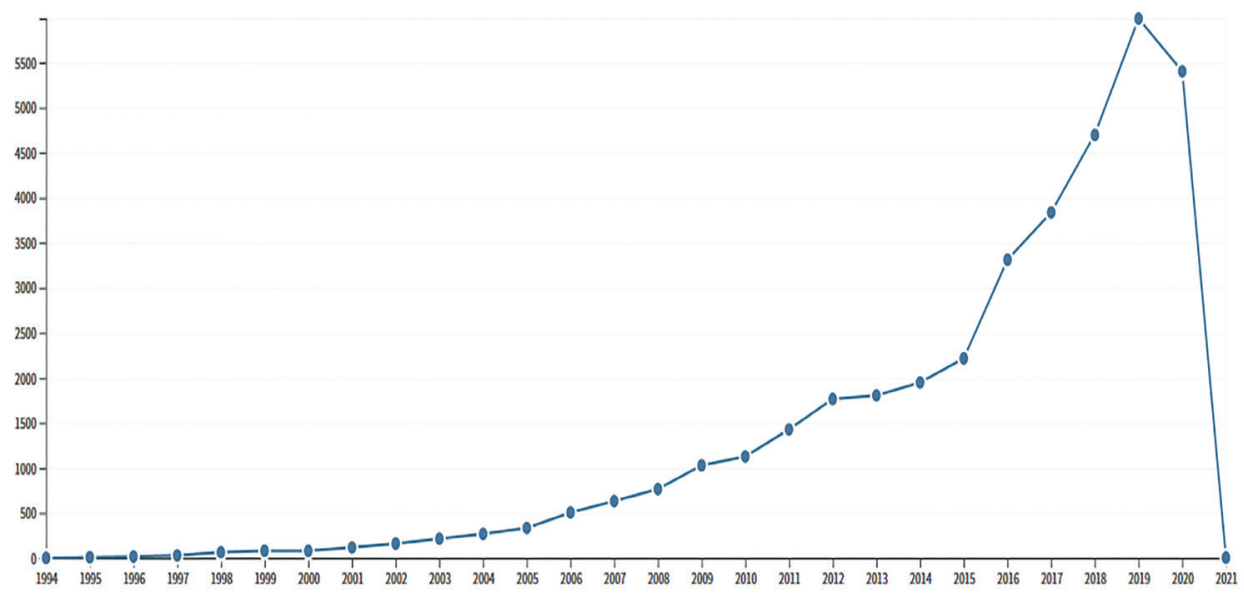

${ }^{11}$ Citation report WoSCC (2020, ORGANIZATION-ENHANCED: (University of Sarajevo) NOT TOPIC: (Int Univ Sarajevo) NOT TOPIC: (Burch). Indexes: SCI-EXPANDED, SSCI, A\&HCI, ESCI). 


\section{Institutes, Scientific Research Centers and Technology Parks}

According to the Answers to additional questions from the Questionnaire of the European Commission, ${ }^{12}$ in the Federation of Bosnia and Herzegovina there are about 20 institutes within faculties or universities and a dozen institutes as independent legal entities. The terminology used ("about", "dozen") indicates the problem of the lack of a clear way of collecting basic data on institutes. How, then, can the position of these institutes be expected to improve? The information for Republika Srpska is somewhat more precise. There are a total of 30 institutes in this entity, of which 12 are at public universities, eight at private universities and ten are independent institutes.

In the mentioned Strategy for the Development of Scientific Research / Artistic Research at the University of Sarajevo, technology/science and technology parks are defined as organizations whose main task is to promote innovation and cooperative activity of entrepreneurs and research institutions with the potential to raise competitiveness. These organizations manage the flow of knowledge and technology between universities, research and development institutions and businesses. This enables the creation and establishment of companies based on innovations through spin-offs and start-up businesses. The primary task of such centres is to generate innovative solutions arising from the activities of scientific research entities (faculties, academies, institutes, laboratories, institutes, etc.) and to establish links and translate innovations into the business sector. There are currently four technology parks in the Federation of Bosnia and Herzegovina: Technopark in Zenica, INTERA in Mostar, BIT Centre in Tuzla and HUB 387 in Sarajevo. The question is to what extent these technology parks fit into the above definition of science and technology parks. In Republika Srpska, there is the Innovation Centre Banja Luka (ICBL), which supports the development of companies with the potential to offer the market commercial solutions in the form of products, services and business processes, based on knowledge and application of innovative and advanced technologies. The Ministry of Science and Technology maintains the Register of legal and natural persons engaged in technology development. Organizations for infrastructural support for technology development are: Foundation Innovation Centre Banja Luka, University-Entrepreneurship Centre Banja Luka, Business Incubator Gradiška, Technology Business Park

\footnotetext{
${ }^{12}$ See: Responses to the European Commission Questionnaire - Chapter 25 - Science and Research, Directorate for European Integration of the Council of Ministers of Bosnia and Herzegovina, DEI | Odgovori na Upitnik EK.
} 
Banja Luka (since 2015 transformed into the business zone "Ramići-Banja Luka") and Technology Centre "LANACO" Banja Luka.

Among the mentioned institutes, scientific research centres and technology parks, there is no mention of the newly established Centre for Research and Development (R\&D Centre) of the University of Sarajevo, as well as the public institution "Centre for Advanced Technologies in Sarajevo". For the implementation of the strategic goals of the mentioned Strategy for the Development of Scientific Research / Artistic Research at the University of Sarajevo, it is important to establish a Centre for Research and Development "which will contribute to establishing the University of Sarajevo as a leading institution in research, creation and implementation of scientific and development projects, as well as strengthening cooperation with the public, private and non-governmental sectors in our country. On the other hand, the application and implementation of the EU and other international projects, but also more intensive cooperation with the business sector will provide significant resources for financial and other support not only for applied but also for fundamental research and professional development and greater mobility of scientists and researchers. The establishment of such a centre will certainly enhance the integration of the University of Sarajevo into the European Higher Education Area (EHEA) and the European Research Area (ERA) and strengthen R\&D cooperation internationally. The UNSA Research and Development Centre will be an integrated centre that will include three core areas:

- innovations, incubator and science / technology park through the "Open innovation" model which is an increasingly common model of organization and management of innovation, and includes R\&D cooperation of all key stakeholders in order to create completely new products, processes and the like. In addition to adequate support for start-up projects, the R\&D centre will also coordinate their implementation and commercialization of innovations through spin-off companies. This component implies significant involvement of young researchers and students;

- excellence and institutionalized approach to the development and transfer of best practices including support to UNSA teaching and research staff in the context of their professional development, research, education, intellectual property protection (spin-off), etc;

- EU and domestic projects: most of the implemented projects, whether international (EU) or domestic projects, depend on the individual engagement of individual researchers without any systemic support. Also, there is a disproportionate number of projects in which UNSA has the 
role of a partner institution and not the role of coordinator or lead partner. By establishing the UNSA Research and Development Centre as an integrated mechanism of institutional support for project activities at our University, this ratio would be significantly improved, and a special contribution to the quality of written and implemented projects would be provided through multidisciplinary project teams and modern project portfolio management mechanisms and use of resources."

\section{Statistical Data on Scientific Research Work. Patents}

The Agency for Statistics of B\&H publishes the announcement "Patents" as a result of processing data taken from the Institute for Intellectual Property of Bosnia and Herzegovina. Data were obtained according to defined tables and processed according to the given methodology. Table 7 shows the patents in the period 2010-2016. It is interesting to note that the number of foreign applicants is significantly higher than the number of domestic patent applicants. In addition, the number of patents is continuously declining. It is obvious that our society does not stimulate innovations and patents. In 2019, six patents were granted in the national procedure, of which only one was a domestic applicant and five were foreign applicants. ${ }^{13}$

Table 7. Patents granted in national proceedings, B\&H 2010-2016.

\begin{tabular}{lccccccc}
\hline & 2010 & 2011 & 2012 & 2013 & 2014 & 2015 & 2016 \\
\hline Total & 207 & 148 & 99 & 85 & 45 & 30 & 13 \\
\hline Domestic applicants & 29 & 36 & 16 & 7 & 2 & 12 & 0 \\
\hline Physical persons & 28 & 34 & 16 & 6 & 2 & 11 & 0 \\
\hline Legal persons & 1 & 2 & 0 & 1 & 0 & 1 & 0 \\
\hline Foreign applicants & 178 & 112 & 83 & 78 & 43 & 18 & 13 \\
\hline Physical persons & 7 & 5 & 4 & 5 & 0 & 0 & 2 \\
\hline Legal persons & 171 & 107 & 79 & 73 & 43 & 18 & 11 \\
\hline
\end{tabular}

By analyzing the content presented on the website of the Agency for Statistics of Bosnia and Herzegovina ${ }^{14}$ we concluded that the way of collecting statistical data on scientific research should be improved. For example,

\footnotetext{
${ }^{13} \mathrm{http}: / /$ bhas.gov.ba/data/Publikacije/Saopstenja/2020/EDU_06_2018_Y1_0_BS.pdf

${ }^{14}$ www.bhas.gov.ba
} 
according to the Agency for Statistics of Bosnia and Herzegovina, ${ }^{15}$ the number of scientific papers published in higher education in 2018 in the field of natural sciences is 18 . However, the actual number should be far higher. 18 papers were published by the Department of Physics of the Faculty of Science at the University of Sarajevo alone. According to Table 5, the Faculty of Science (PMF) and the Institute of Genetic Engineering and Biotechnology (INGEB) published 146 papers in natural sciences in 2018 (these papers were the basis for the awards and were registered in the Web of Science Core database). If other less significant databases are taken into account, the number of published works is much higher.

\section{Financing and Problems of Realization of Employment of Scientists and Researchers}

In this paper we do not analyze the problems of financing scientific research in Bosnia and Herzegovina, but we point out that, even if funds are obtained for scientific research jobs, the problem is the lack of mechanisms for the implementation of employment (requires the approval of the government or competent authorities, and they limit the number of jobs). Legislation and the "social atmosphere" need to be changed in parallel with the approval of funding for science. Taking into account the small number of young scientists and researchers in Bosnia and Herzegovina, it would be especially important to plan financial resources from the budget for providing scientific research to youth, i.e. employment of young assistants and researchers. At the same time, we should work on changing the personnel policy, developing international cooperation (with special emphasis on our scientific diaspora) and introducing special measures that would enable the return of the best students and scientists to Bosnia and Herzegovina.

\section{Conclusions}

In this paper, we have pointed out some of the possibilities of eliminating the difficulties encountered by the universities of Bosnia and Herzegovina in advancing science and shaping the system of science and scientific research. In the ranking of countries in the world according to The SCImago Journal \& Country Rank portal, Bosnia and Herzegovina is currently ranked

\footnotetext{
${ }^{15} \mathrm{http} / / /$ bhas.gov.ba/data/Publikacije/Saopstenja/2019/RDE_01_2018_Y1_0_BS.pdf 
90th, and the best ranked university in Bosnia and Herzegovina according to Webometrics is the University of Sarajevo (1508th place). These results, if we take into account the specific constitutional and territorial organization of Bosnia and Herzegovina and the problems caused by the war and post-war transition, are not so bad. However, the lag in relation to the neighboring countries of Croatia and Serbia is too large and changes are necessary. Within the project "Harmonization of the system of science in Bosnia and Herzegovina" of the Academy of Sciences and Arts of Bosnia and Herzegovina, and in this collection of papers, the emphasis is on the harmonization of the system of science through the legislation of competent territorial units in Bosnia and Herzegovina. In this paper, the emphasis is on an alternative approach to improve the position of science and scientific research in Bosnia and Herzegovina. It is a "bottom-up" approach according to which universities, institutes and other bearers of the development of science and scientific research, as well as individuals engaged in scientific research, can do much to improve the position of science, without waiting for changes to existing and new laws. Examples of such an approach are the Strategy for the Development of Scientific Research and the Regulation on Rewarding Based on the Results of Scientific Research at the University of Sarajevo. In addition, using examples of statistical data on scientific research and patents (there is only one recognized domestic patent in Bosnia and Herzegovina in 2019), the need to improve the way of collecting statistical data on scientific research was pointed out. We hope that this paper and the above examples will serve as a guide on how the individual efforts and actions of the universities and institutes themselves can improve the position of science in Bosnia and Herzegovina.

\section{References}

Trifković, M. (2020). Harmonization of the Science System in Bosnia and Herzegovina. Academy of Sciences and Arts of Bosnia and Herzegovina. Special Editions. Volume CLXXXV. Systems Research Center. Volume 5/1. Sarajevo.

Guerrero-Botea, V. P. and Moya-Anegón, F. (2012). A further step forward in measuring journals' scientific prestige: The SJR2 indicator. Journal of Informetrics, Vol. 6, pp. 674-688. ISSN: $1751-1577$ 